OPEN ACCESS

Edited by:

E. Christien Michael Parsons, University of Glasgow,

United Kingdom

Reviewed by:

Douglas Fenner,

Independent Researcher, Pago Pago,

American Samoa

Matthew David Tietbohl,

King Abdullah University of Science

and Technology, Saudi Arabia

${ }^{*}$ Correspondence:

Mathinee Yucharoen

mathinee_yucharoen@hotmail.com

Specialty section:

This article was submitted to Marine Conservation

and Sustainability,

a section of the journal

Frontiers in Marine Science

Received: 08 November 2018

Accepted: 17 February 2020

Published: 18 March 2020

Citation:

Yucharoen M, Chankong A,

Phongsuwan N, Ninwat S,

Darumas U, Thongkao S and

Phasombun S (2020) Coral Diversity at Losin Pinnacle, an Offshore Reef

in the Gulf of Thailand: Toward

a Future MPA. Front. Mar. Sci. 7:130.

doi: 10.3389/fmars.2020.00130

\section{Coral Diversity at Losin Pinnacle, an Offshore Reef in the Gulf of Thailand: Toward a Future MPA}

\author{
Mathinee Yucharoen ${ }^{1,2 *}$, Anchalee Chankong ${ }^{3}$, Niphon Phongsuwan ${ }^{3}$, Santi Ninwat ${ }^{3}$, \\ Udomsak Darumas ${ }^{4}$, Suthira Thongkao ${ }^{5}$ and Supaporn Phasombun ${ }^{4}$
}

${ }^{1}$ Marine and Coastal Resources Institute, Faculty of Environmental Management, Prince of Songkla University, Hat Yai, Thailand, ${ }^{2}$ Coastal Oceanography and Climate Change Research Center, Prince of Songkla University, Hatyai, Thailand, ${ }^{3}$ Department of Marine and Coastal Resources, Ministry of Natural Resources and Environment, Bangkok, Thailand, ${ }^{4}$ School of Science, Walailak University, Nakhon Si Thammarat, Thailand, ${ }^{5}$ School of Engineering and Resources, Walailak University, Nakhon Si Thammarat, Thailand

Severe coral bleaching events in the Gulf of Thailand and along the Andaman Sea coast of Thailand caused widespread coral mortality in 1998 and 2010. The consequent decrease in coral populations impacted the structure, health, and services of Thai coral reefs. However, most colonies in the offshore reef of Losin were still alive after the coral bleaching events. Therefore, this study was conducted by the Department of Marine and Coastal Resources in order to help to establish a proposal for making it a Marine Protected Area (MPA). Surveys on coral diversity were conducted to produce a checklist of reef-building corals. Seventy-six coral species were found, with the most dominant species being Porites lutea and Acropora communities, such as A. intermedia, A. grandis, A. muricata, $A$. cytherea, and $A$. valenciennesi. This area is expected to be designated as a restricted MPA area, under the "Act on the Promotion of Marine and Coastal Resources Management B.E. 2558 (2015)." The high diversity of hard corals discovered in this study assists in promoting an Announcement of the Losin Marine and Coastal Resources Protected Areas following Ministerial Regulation.

Keywords: Acropora, coral bleaching, protected area, management, Gulf of Thailand

\section{INTRODUCTION}

Coral reefs are one of the most vulnerable marine ecosystems to elevated sea temperature, and this has resulted in global coral bleaching (Moss et al., 2010; Hoegh-Guldberg, 2011; Burke et al., 2012; Kennedy et al., 2013; Graham et al., 2015; Hughes et al., 2017; Gintert et al., 2018). Predictions of annual coral bleaching occurring in the next 30 years are alarming due to the likelihood of increased frequency and severity (Manzello, 2015; Hughes et al., 2017). Increased coral bleaching and thermal stress impact hard coral species differently, with some species suffering significantly more mortality than others (Guest et al., 2012; Wooldridge, 2014). Thermal stress has not only been a concern for susceptible corals but is also a threat to coral reef health in terms of coral diseases (Gintert et al., 2018). Temperature-stressed corals could be more susceptible to opportunistic pathogens, which may be associated with subsequent diseases (Precht et al., 2016; Raymundo et al., 2018).

Widespread coral mortality from mass coral bleaching events between 1998 and 2010 in Thai waters has been reported previously (Yeemin et al., 2009; Phongsuwan and Chansang, 2012; 
Sutthacheep et al., 2013; Yucharoen et al., 2015). Coral reefs along the Gulf of Thailand experienced high mortality, and a subsequent loss of Acropora species was reported in the region (Yeemin et al., 2009; Hoeksema et al., 2013). High losses of Acropora corals from these reefs were alarming, as some Acropora species could face functional extinction in the eastern Gulf of Thailand (Yeemin et al., 2013b). Additionally, the rapid growth of tourism, meaning an increased number of people visiting the reefs, led to additional physical damage, resulting in the temporary closure of dive sites, especially those in Marine National Parks (Yeemin, 2012).

The offshore reef at Losin Pinnacle appeared to be only minorly impacted by the mass coral bleaching that occurred in 2010, with relatively high live coral cover after the bleaching event. After the third global bleaching event in 2016, Sutthacheep et al. (2019) noted a decrease in bleaching relative to past bleaching events, with only $5 \%$ of the corals bleached. This mild bleaching could be due to its local conditions: surrounded by open sea, with strong currents and internal waves, which could dampen the impacts of increased temperature (Williams et al., 2010; Schmidt et al., 2016). The fishing activity around Losin Pinnacle may be an additional source of damage, as ghost fishing nets and gear have recently been found covering parts of the reef (Marine and Coastal Resources Research and Development Institute, 2018). The goal of this study was to supply the Ministry of Natural Resources and Environment with adequate information on the coral diversity and abundance found at Losin Pinnacle to establish baseline values for the reef in support of a marine protected area (MPA) proposal.

\section{MATERIALS AND METHODS}

Losin Pinnacle (Figure 1) is used as a base for lighthouse operations approximately $72 \mathrm{~km}$ from shore and is also known as one of the most southern popular dive sites in the Gulf of Thailand (844 SCUBA dives were recorded in 2017). This area is dominated by annual southwest and northeast monsoons during May-October and November-February, respectively. The wind speed toward the southwest direction is mostly higher than in other directions (Supplementary Table S1). An islet area is slightly above sea level, and the sea had a very small tidal range of about $50 \mathrm{~cm}$ (Supplementary Table S2). Surveys were conducted between 2015 and 2017 at six locations surrounding the reef. Belt transects, $30 \mathrm{~m}$ long $\times 2 \mathrm{~m}$ wide, with three replicates, were set parallel to the shore of the pinnacle in an anticlockwise direction at ST1-ST6 (Figure 1). Sites ST1, ST3, and ST5 were fixed at $20 \mathrm{~m}$ in depth for deep transects, whereas ST2, ST4, and ST6 were fixed at $10 \mathrm{~m}$ in depth for shallow transects. Underwater photographs $(n=60)$ were taken along each transect for assessment of benthic percentage cover. All images were analyzed by Coral Point Count with Excel extensions, using CPCe software (Kohler and Gill, 2006), and the benthic percentage was calculated. Coral species were recorded using a combination of belt transects and roving driver survey outside the belt transects in order to better assess true coral species diversity. The roving searches were done in shallow and deep areas, near the belt transects, covering 10-15 $\mathrm{m}$ and 20$25 \mathrm{~m}$ in depth, respectively. Coral photographs were taken, and some coral samples were collected for microscopic investigation when the researchers could not identify them in situ. All species were identified by morphological characteristics according to http://www.coralsoftheworld.org and others (Veron and Pichon, 1976, 1980, 1982; Veron et al., 1977; Veron and Wallace, 1984; Hoeksema, 1989; Wallace, 1999; Veron, 2000; Wallace et al., 2012). Genetic identification was not used in this study due to cost limitations. In addition, environmental parameters were measured in situ at sites ST1, ST3, ST5, and ST7 during August 28-30, 2017. The seawater temperature, salinity, $\mathrm{pH}$, and dissolved oxygen data were recorded at $5 \mathrm{~m}$ depth from the sea surface by YSI Pro Plus Multi-Parameter Water Quality Meter (YSI Incorporated, Xylem Inc.), and the visibility distance was measured by Secchi disk (Supplementary Table S3).

\section{RESULTS}

Losin Pinnacle consists of a reef area encompassing about $65,000 \mathrm{~m}^{2}$ and is associated with good water quality. The reef compositions on the south and west sides were different from on the east due to different levels of exposure to waves. As shown in Figure 2, it is clear that sites ST1-ST4 had high live coral coverage; $97 \%, 85 \%, 77 \%$, and 95\%, respectively. Dense Acropora communities at those sites included A. intermedia, A. grandis, A. hyacinthus, and several corymbose species. Some Montipora, Porites, and Pocillopora were found interspersed. Live corals at sites ST5 and ST6 showed lower percentage coverage, at 45\% and $52 \%$ live hard coral cover, respectively. This windward side was dominated by large colonies of Porites, Pocillopora, and some branching Acropora.

A total of 76 hard coral species (Supplementary Data Sheet 1) were found, with Acropora species representing the largest number of species. The most dominant Acropora species were the arborescent, i.e., A. grandis, A. intermedia, and A. muricata, and the tabulate forms, i.e., A. cytherea, and $A$. solitaryensis. The other common Acropora species were of various forms; tabulate (A. hyacinthus, A. subulata), arborescent (A. florida, A. robusta), corymbose (A. divaricata, A. hoeksemai, A. latistella), and corymbo-tabulate (A. valenciennesi).

\section{DISCUSSION}

Highly abundant and diverse Acropora populations are uncommon on most inshore reefs in the Gulf of Thailand, making the coral community at Losin Pinnacle a unique potential reservoir of Acropora diversity. After the 2010 bleaching event, coral communities in the Gulf of Thailand have been dominated by bleaching-resistant taxa, with a lower coral diversity than in previous periods (Sutthacheep et al., 2013, 2019). Losin Pinnacle has a much higher species diversity, over 75 species, compared to other Thai reefs; 47 species were recorded from twelve sites in the Andaman Sea (Phongsuwan 


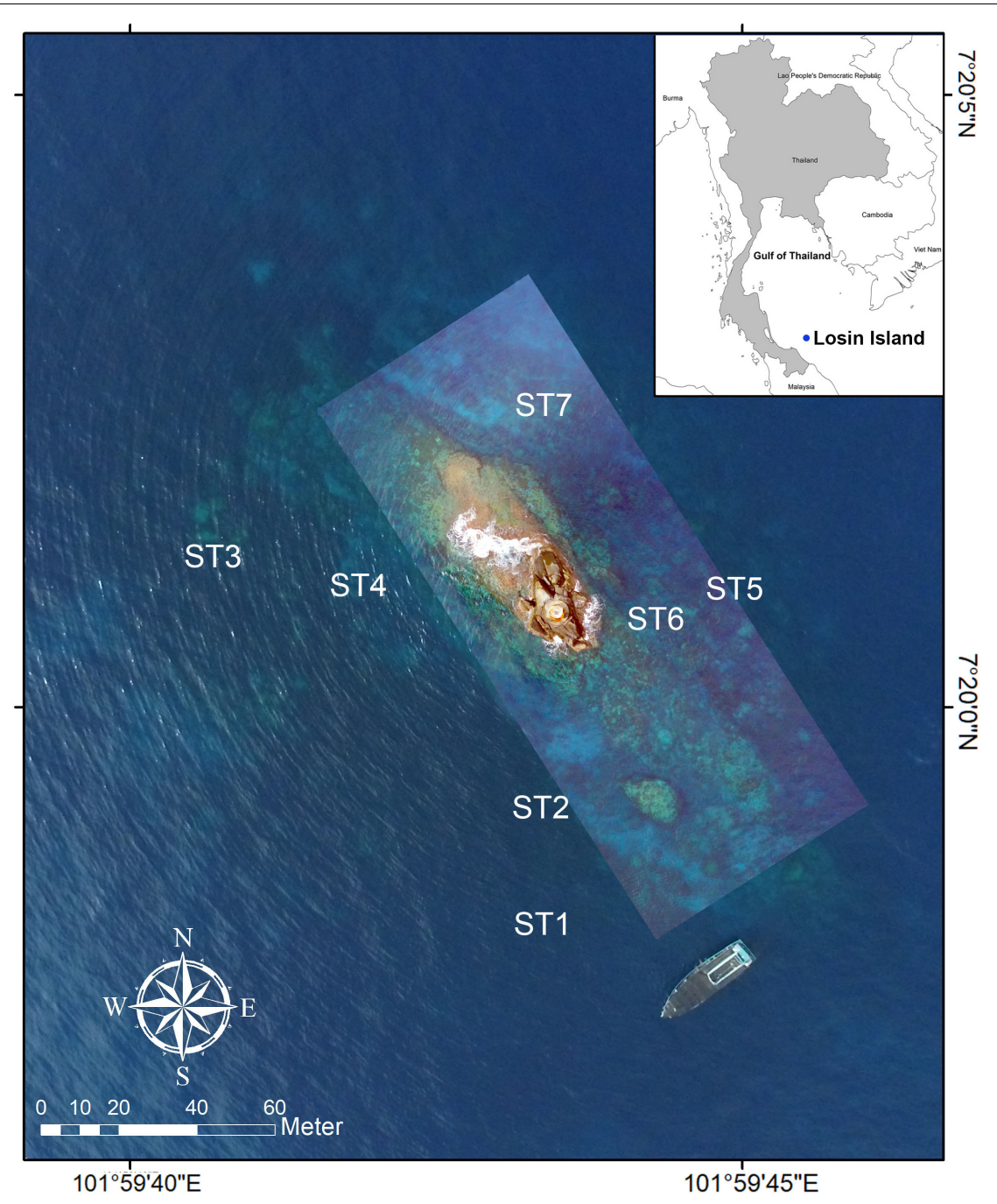

FIGURE 1 | Location of Losin Pinnacle; 7.33360051658N, 101.995261722 E. Shallow survey sites at $10 \mathrm{~m}$ comprise ST2, ST4, and ST6, while deep surveys at 20 m comprise sites ST1, ST3, and ST5. All surveys were conducted in an anticlockwise direction, staying parallel to the actual pinnacle. Sites ST1, ST3, ST5, and ST7 were used to collect physical environmental measurements.

and Chansang, 2012), and only 44 species were recorded from six sites in the Gulf of Thailand (Yeemin et al., 2009; Sutthacheep et al., 2012, 2013). Though the overall area of the reef at Losin Pinnacle is relatively small, the coverage of live coral is high relative to other Thai reefs, which typically have live coral cover ranging from approximately $8 \%$ to $45 \%$ (Phongsuwan et al., 2013; Yeemin et al., 2013a; Sutthacheep et al., 2015). Additionally, Losin reef is rich in fish (111 species, personal communication), and other benthic organisms such as ascidians, octocorals, echinoderms, crustaceans, and sponges (Darumas et al., 2018; Marine and Coastal Resources Research and Development Institute, 2018).

This reef should be considered as a restricted area in which there would be appropriate conservation strategies; specifically, an MPA. The designated MPA would also aim to integrate social and ecological aspects, as previous successful MPAs have done, to increase its effectiveness (Ban et al., 2011). Although it would not be protected against high seawater temperature, setting up an MPA with proper enforcement would reduce the vulnerability of corals to anthropogenic disturbances (Keller et al., 2009; Selig and Bruno, 2010; Wilson et al., 2012) through restricting use of the sea around Losin Pinnacle and limiting excessive use of the reef by tourists or fishermen.

Our baseline coral data, along with awareness and education sessions on coral bleaching, have encouraged the authority (Department of Marine and Coastal Resources) to draft an MPA plan for Losin Reef. After conducting the final public hearing with relevant agencies and stakeholders on October 2018, the proposal submitted to the National Policy and Plan Committee on Marine and Coastal Resources is currently under discussion, and in the future, hopefully, the MPA will be enacted. The next step will be preparation for the legal act, and it is expected to be put into force by the end of 2020. It is strongly suspected that the output from this study will actively support 


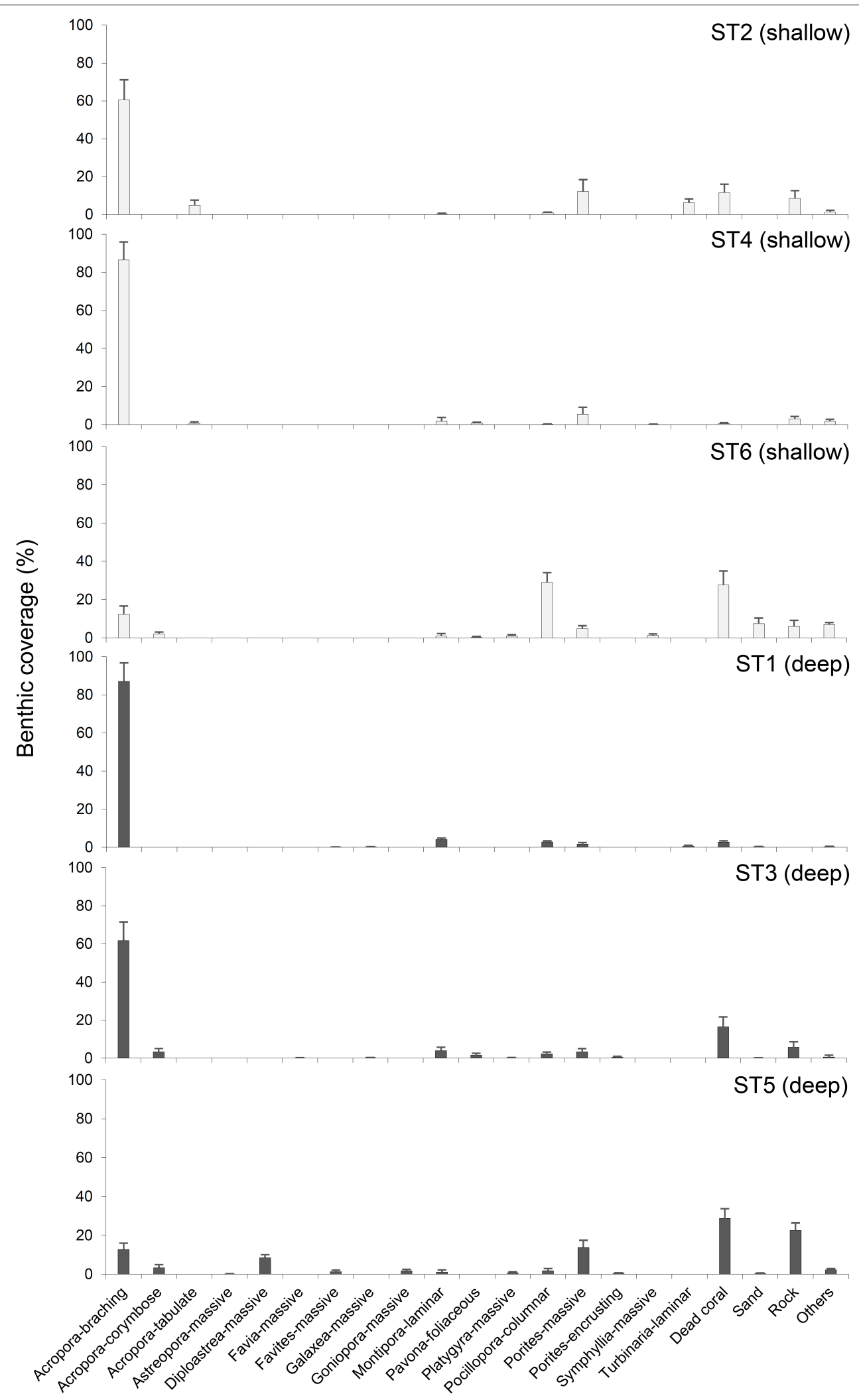

FIGURE 2 | Benthic cover data (mean + SD) observed from three shallow (10 m) and three deep (20 m) stations around Losin Pinnacle during August 2017.

Percentage cover was calculated from photographs taken every half meter with three replicates at 30 -m belt transects. Corals were divided into growth forms, and several abiotic variables were measured. Others represent benthic organisms other than hard corals. 
Thailand's management plan under the Act on the Promotion of Marine and Coastal Resources Management B.E. 2558 (2015). The importance of Losin Pinnacle as a source of coral diversity for other reefs and as a potentially resilient reef to increased ocean temperatures should be further assessed in the future for population genetics and oceanographic studies.

\section{DATA AVAILABILITY STATEMENT}

The raw data supporting the conclusion of this article will be made available by the authors, without undue reservation, to any qualified researcher.

\section{AUTHOR CONTRIBUTIONS}

MY, AC, SN, and UD conceived and planned the main idea. SN supervised the project for surveying the coral reef at Losin Pinnacle and planned the underwater coral studies. NP, MY, and AC contributed to sample collection and the identification of corals. MY, NP, and SN contributed to the data collection and analyzed coral reef status. MY and NP interpreted the results with support from AC. UD, ST, and SP wrote the project on "Draft of the Announcement of the Losin Pinnacle Marine Resources Protected Area" and contributed to public hearings with the support of MY. MY performed the data analysis and wrote the manuscript with support from NP and AC. MY, AC, NP, and SN provided Supplementary Material. All of the authors carried out the field studies and discussed the results related to the final manuscript.

\section{REFERENCES}

Ban, N. C., Adams, V. M., Almany, G. R., Ban, S., Cinner, J. E., McCook, L. J., et al. (2011). Designing, implementing and managing marine protected areas: emerging trends and opportunities for coral reef nations. J. Exp. Mar. Biol. Ecol. 408, 21-31. doi: 10.1016/j.jembe.2011.07.023

Burke, L., Reytar, K., Spalding, M. D., and Perry, A. (2012). Reefs at Risk Revisited in the Coral Triangle. Washington DC: World Resources Institute.

Darumas, U., Phasombun, S., and Puttapreecha, R. (2018). Patterns of association between marine sponges and the associated organisms: case study, Losin Island, Pattani Thailand. Walailak J. Sci. Tech. 17. doi: 10.14456/vol17iss1pp

Gintert, B. E., Manzello, D. P., Enochs, I. C., Kolodziej, G., Carlton, R., Gleason, A. C. R., et al. (2018). Marked annual coral bleaching resilience of an inshore patch reef in the florida keys: a nugget of hope, aberrance, or last man standing? Coral Reefs 37, 533-547. doi: 10.1007/s00338-018-1678-x

Graham, N. A. J., Jennings, S., MacNeil, M. A., Mouillot, D., and Wilson, S. K. (2015). Predicting climate-driven regime shifts versus rebound potential in coral reefs. Nature 518, 94-97. doi: 10.1038/nature14140

Guest, J. R., Baird, A. H., Maynard, J. A., Muttaqin, E., Edwards, A. J., Campbell, S. J., et al. (2012). Contrasting patterns of coral bleaching susceptibility in 2010 suggest an adaptive response to thermal stress. PLoS One 7:e33353. doi: 10.1371/journal.pone.0033353

Hoegh-Guldberg, O. (2011). Coral reef ecosystems and anthropogenic climate change. Reg. Environ. Chang. 11, 215-227. doi: 10.1007/s10113-010-0189-2

Hoeksema, B. W. (1989). Taxonomy, phylogeny and biogeography of mushroom corals (Scleractinia: Fungiidae). Zool. Verh. Leiden. 254, 1-295.

Hoeksema, B. W., Scott, C., and True, J. D. (2013). Dietary shift in corallivorous Drupella snails following a major bleaching event at Koh Tao, Gulf of Thailand. Coral Reefs 32, 423-428. doi: 10.1007/s00338-012-1005-x

\section{FUNDING}

The funding was supported by the Department of Marine and Coastal Resources (DMCR), Ministry of Natural Resources and Environment, Thailand, under the project on "Draft of the Announcement of the Losin Pinnacle Marine Resources Protected Area" no. 37/25613.

\section{ACKNOWLEDGMENTS}

The authors are most grateful to the committee members who organized the 5th International Marine Conservation Congress, where this research was published as a conference manuscript and is now being extended to this brief research report. The authors would like to express their gratitude to the Marine Biodiversity Research Group, Ramkhamhaeng University, and the Marine Science Association of Thailand for providing public venues for presenting this project. They would also like to thank the staff of the Marine and Coastal Resources Research and Development Center, Lower Gulf of Thailand, Walailak University, and students belonging to the Coastal Oceanography and Climate Change Research Center, Prince of Songkla University, for their assistance in the fieldwork.

\section{SUPPLEMENTARY MATERIAL}

The Supplementary Material for this article can be found online at: https://www.frontiersin.org/articles/10.3389/fmars. 2020.00130/full\#supplementary-material

Hughes, T. P., Kerry, J. T., Álvarez-Noriega, M., Álvarez-Romero, J. G., Anderson, K. D., Baird, A. H., et al. (2017). Global warming and recurrent mass bleaching of corals. Nature 543, 373-377. doi: 10.1038/nature21707

Keller, B. D., Gleason, D. F., McLeod, E., Woodley, C. M., Airamé, S., Causey, B. D., et al. (2009). Climate change, coral reef ecosystems, and management options for marine protected areas. Environ. Manag. 44, 1069-1088. doi: 10. 1007/s00267-009-9346-0

Kennedy, E. V., Perry, C. T., Halloran, P. R., Iglesias-Prieto, R., Schönberg, C. H. L., Wisshak, M., et al. (2013). Avoiding coral reef functional collapse requires local and global action. Curr. Biol. 23, 912-918. doi: 10.1016/j.cub.2013.04.020

Kohler, K. E., and Gill, S. M. (2006). Coral point count with excel extensions (CPCe): a visual basic program for the determination of coral and substrate coverage using random point count methodology. Comput. Geosci. 32, 12591269. doi: 10.1016/j.cageo.2005.11.009

Manzello, D. P. (2015). Rapid recent warming of coral reefs in the Florida Keys. Sci. Rep. 5:16762. doi: 10.1038/srep16762

Marine and Coastal Resources Research and Development Institute (2018). Losin Pinnacle. Biodiversity colour of the ocean. Bangkok: Ministry of Natural Resources and Environment.

Moss, R. H., Edmonds, J. A., Hibbard, K. A., Manning, M. R., Rose, S. K., Van Vuuren, D. P., et al. (2010). The next generation of scenarios for climate change research and assessment. Nature 463, 747-756. doi: 10.1038/nature08823

Phongsuwan, N., Chankong, A., Yamarunpatthana, C., Chansang, H., Boonprakob, R., Petchkumnerd, P., et al. (2013). Status and changing patterns on coral reefs in Thailand during the last two decades. Deep. Res. Part II Top. Stud. Oceanogr. 96, 19-24. doi: 10.1016/j.dsr2.2013.02.015

Phongsuwan, N., and Chansang, H. (2012). Repeated coral bleaching in the Andaman Sea, Thailand, during the last two decades. Phuket Mar. Biol. Cent. Res. Bull. 71, 19-41. 
Precht, W. F., Gintert, B. E., Robbart, M. L., Fura, R., and van Woesik, R. (2016). Unprecedented disease-related coral mortality in Southeastern Florida. Sci. Rep. 6:31374. doi: 10.1038/srep31374

Raymundo, L. J., Licuanan, W. Y., and Kerr, A. M. (2018). Adding insult to injury: ship groundings are associated with coral disease in a pristine reef. PLoS One 13:e0207078. doi: 10.1371/journal.pone.0207078

Schmidt, G. M., Wall, M., Taylor, M., Jantzen, C., and Richter, C. (2016). Largeamplitude internal waves sustain coral health during thermal stress. Coral Reefs 35, 1-13. doi: 10.1007/s00338-016-1450-z

Selig, E. R., and Bruno, J. F. (2010). A global analysis of the effectiveness of marine protected areas in preventing coral loss. PLoS One 5:e9278. doi: 10.1371/journal. pone.0009278

Sutthacheep, M., Chamchoy, C., Pengsakun, S., Klinthong, L., and Yeemin, T. (2019). Assessing the resilience potential of inshore and offshore coral communities in the Western Gulf of Thailand. J. Mar. Sci. Eng. 7:408. doi: 10.3390/jmse7110408

Sutthacheep, M., Saenghaisuk, C., Pengsakun, S., Donsomjit, W., and Yeemin, T. (2015). Quantitative studies on the 2010 mass coral bleaching event in Thai waters. Galaxea 15, 379-390. doi: 10.3755/galaxea.15.379

Sutthacheep, M., Yucharoen, M., Klinthong, W., Pengsakun, S., Sangmanee, K., and Yeemin, T. (2012). Coral mortality following the 2010 mass bleaching event at Kut Island, Thailand. Phuket Mar. Biol. Cent. Res. Bull. 71, 83-92.

Sutthacheep, M., Yucharoen, M., Klinthong, W., Pengsakun, S., Sangmanee, K., and Yeemin, T. (2013). Impacts of the 1998 and 2010 mass coral bleaching events on the Western Gulf of Thailand. Deep. Res. Part II Top. Stud. Oceanogr. 96, 25-31. doi: 10.1016/j.dsr2.2013.04.018

Veron, J. E. N. (2000). Corals of the World. Townsville: Australian Institute of Marine Science.

Veron, J. E. N., and Pichon, M. (1976). Schleractinia of Eastern Australia Part 1, Families Thamnasteriidae, Astrocoeniidae, Pocilloporidae. Canberra: Australian Government Publishing Service.

Veron, J. E. N., and Pichon, M. (1980). Schleractinia of Eastern Australia Part 3, Families Agariciidae, Siderastreidae, Fungiidae, Oculinidae, Merulinidae, Mussidae, Pectiniidae, Caryophylliidae, Dendrophylliidae. Canberra: Australian Government Publishing Service.

Veron, J. E. N., and Pichon, M. (1982). Schleractinia of Eastern Australia Part 4, Family Poritidae. Canberra: Australian Government Publishing Service.

Veron, J. E. N., Pichon, M., and Wijsman-Best, M. (1977). Schleractinia of Eastern Australia Part 2, Families Faviidae, Trachyphylliidae. Canberra: Australian Government Publishing Service.

Veron, J. E. N., and Wallace, C. C. (1984). Schleractinia of Eastern Australia Part 5, Family Acroporidae. Canberra: Australian Government Publishing Service.

Wallace, C. C. (1999). Staghorn Corals of the World. A Revision of the Genus Acropora. Collingwood: CSIRO Publishing.
Wallace, C. C., Phongsuwan, N., and Muir, P. R. (2012). A new species ofstaghorn coral, Acropora sirikitiae sp. nov (Scleractinia: Astrocoenina: Acroporidae) from western Thailand. Phuket Mar. Biol. Cent. Res. Bull. 71, 117-125.

Williams, G. J., Knapp, I. S., Maragos, J. E., and Davy, S. K. (2010). Modeling patterns of coral bleaching at a remote Central Pacific atoll. Mar. Pollut. Bull. 60, 1467-1476. doi: 10.1016/j.marpolbul.2010.05.009

Wilson, S. K., Graham, N. A. J., Fisher, R., Robinson, J., Nash, K., Chong-Seng, K., et al. (2012). Effect of macroalgal expansion and marine protected areas on coral recovery following a climatic disturbance. Conserv. Biol. 26, 995-1004. doi: 10.1111/j.1523-1739.2012.01926.x

Wooldridge, S. A. (2014). Differential thermal bleaching susceptibilities amongst coral taxa: re-posing the role of the host. Coral Reefs 33, 15-27. doi: 10.1007/ s00338-013-1111-4

Yeemin, T. (2012). "Impacts of coral bleaching, recovery and management in Thailand," in Proceedings of the 12th International Coral Reef Symposium, Cairns.

Yeemin, T., Pengsakun, S., Yucharoen, M., Klinthong, W., Sangmanee, K., and Sutthacheep, M. (2013a). Long-term changes in coral communities under stress from sediment. Deep. Res. Part II Top. Stud. Oceanogr. 96, 32-40. doi: 10.1016/ j.dsr2.2013.04.019

Yeemin, T., Pengsakun, S., Yucharoen, M., Klinthong, W., Sangmanee, K., and Sutthacheep, M. (2013b). Long-term decline in Acropora species at Kut Island, Thailand, in relation to coral bleaching events. Mar. Biodivers. 43, 23-29. doi: 10.1007/s12526-012-0138-z

Yeemin, T., Saenghaisuk, C., Sutthacheep, M., Pengsakun, S., Klinthong, W., and Saengmanee, K. (2009). Conditions of coral communities in the Gulf of Thailand: a decade after the 1998 severe bleaching event. Galaxea 11, 207-217. doi: 10.3755/galaxea.11.207

Yucharoen, M., Yeemin, T., Casareto, B. E., Suzuki, Y., Samsuvan, W., Sangmanee, K., et al. (2015). Abundance, composition and growth rate of coral recruits on dead corals following the 2010 bleaching event at Mu Ko Surin, the Andaman Sea. Ocean Sci. J. 50, 307-315. doi: 10.1007/s12601-015-0028-y

Conflict of Interest: The authors declare that the research was conducted in the absence of any commercial or financial relationships that could be construed as a potential conflict of interest.

Copyright (C) 2020 Yucharoen, Chankong, Phongsuwan, Ninwat, Darumas, Thongkao and Phasombun. This is an open-access article distributed under the terms of the Creative Commons Attribution License (CC BY). The use, distribution or reproduction in other forums is permitted, provided the original author(s) and the copyright owner(s) are credited and that the original publication in this journal is cited, in accordance with accepted academic practice. No use, distribution or reproduction is permitted which does not comply with these terms. 